\title{
INDICATOR OF ENVIRONMENTAL PROBLEMS OF AGRICULTURAL SECTORS UNDER THE ENVIRONMENTAL MODELING
}

\author{
Pruethsan Sutthichaimethee ${ }^{1, *}$, Yothin Sawangdee ${ }^{1}$ \\ 1 Institute for Population and Social Research, Mahidol University, Nakhonpathom 73170, Thailand \\ * Corresponding Author e-mail: pruethsan@gmail.com
}

Received: 2015.11 .08

Accepted: 2016.03.04

Published: 2016.04.01

\begin{abstract}
The objective of this research is to propose an indicator to deal with environmental problems for agricultural sectors caused by goods and services production. The aspects to calculate the real benefit of agricultural sectors and environmental cost for analyzing are natural resources materials, energy and transportation, fertilizer and pesticides, and sanitary and similar service. From the research it was found that the highest environmental cost of natural resources materials was 026: charcoal and firewood, while the lowest was 010 coconut. The highest environmental cost for energy and transportation was 024: agricultural services, while the highest environmental cost for fertilizer and pesticides was 011: palm oil. lastly, 017: other agricultural products was found as the highest environmental cost for sanitary and similar service. As a result, 010: coconut gained the highest real benefit, while 024: agricultural services presented as the lowest read benefit for the company. If Thailand using environmental problem indicator, especially with the agricultural sector, it can help to formulate efficient policies and strategies for the country in 3 development areas, which are social, economic, and environmental development.
\end{abstract}

Keywords: agricultural sector, revenue, environment cost, forward linkage, multiplier, modeling, sustainable.

\section{INTRODUCTION}

One of the most important factors to develop the country is environmental and natural resources [Asian Development Bank, 2014; TDRI, 2007; Chen, 2010]. However, the social and economic changes in Thailand have caused the deterioration of environmental and natural resources i.e. forest and wild animal, mangrove forest [TDRI, 2007], water resources [Bodini et al., 2002] and waste. Besides, the natural resources have limited amount [Allen et al., 1995], whereas the consumption of natural resources is unlimited [Chen et al.,2010] what causes the environmental and natural resources decreasing immediately [Harwick, 1998] and continuously. The government foresees this issue, therefore, leading them to announce a sustainable development policy that is to increase economic growth together with social and environmental development [TDRI, 2006].
The environmental and natural resources degradation is the first priority for Thai society to make the development plan [ADB, 2014]. The plan must correspond with the economic and social development strategy of Ministry of Natural Resources and Environment [NESDB, 2015].

Marull (2010) stated that the principal policy of the country must realize the following problems and impacts after the policy is implemented. The previous policy, however, did not mainly focus on the environmental issue leading to efficient management of the problems [Simpson, 1996; Marull et al., 2010]. Index of sustainable economic welfare (ISEW) is an indicator to specify sustainable development of the country and economic welfare measurement [McMullan, 2013; Allen et al., 1995; Bodini, 2002]. ISEW does not only consider the consumption value, but this index also concerns unsustainable environmental cost, social cost, and environmental affecting expendi- 
ture [Brent, 2006]. The comparison of ISEW per capita with GDP per capita of Thailand during 1977 to 2003 shows that ISEW per capita before 1977 was consistent with GDP per capita, which the growth rate went positively [ADB, 2014]. However, after 2003 both indexes went conversely and the growth rate decreased [NESDB, 2015]. ISEW per capita decreased by $6.70 \%$,whereas GDP per capita changed by $-0.89 \%$. This information represented that before 1977 ISEW per capita was higher than GDP per capita, but from 2003 ISEW per capita was lower than GDP per capita, because of increasing foreign investments in Thailand [NESDB, 2015]. This is the main factor of the degradation of environmental and natural resources led to the decrease of ISEW per capita [TDRI, 2007]. TDRI reported that the degradation of environmental and natural resources in Thailand is the following;

- Deforestation leads to environmental problem in Thailand.

- Inefficient water resources management causes flood and drought.

- Overfishing causes degradation of fishery resources.

- Increasing air pollution, waste pollution, and water pollution.

Businesses and consumers are the major players in the economic system [Liang, 2009; Li SS, 2012; Kennedy, 2007]. The consumers want to gain high utilization under limited budget, whereas the businesses aim to maximize their profit and reduce expenditure [Lenzen,1998; Pantavisid, 2012; Hugo, 2005; Hugo, 2005]. Neither of them attention to the Environmental Cost causing over consumption and production [ADB, 2014; Benoit, 2009; Chen et al., Duchin, 2008]. However, the sustainable development for the country should develop in 3 scopes collectively [Adams, 2009; Ukaga, 2010], which are economic, social, and environment. Previously, nonetheless, Thailand gave priority to develop only the economic growth. Moreover, NESDB (2015) stated that the firms did not consider the cost from natural resources materials, energy and transportation, fertilizer and pesticides, and sanitary and similar services, which they represent the environmental cost. As a result, it could not lead to sustainable development because the economic growth goes together with higher environmental cost [Brent et al., 2006; Duque, 2010; Grossmann, 2009].

Accordingly, the formulation of policy and strategy to develop the country must concern real benefit and environmental cost in 3 areas [Ukaga, 2010; Bodini, 2002; ADB, 2014; TDRI, 2005; Ness et al., 2007; NESDB, 2015; Salema, 2010]. In addition, environmental problem prioritizing should be clearly classified [ADB, 2014]. All of these factors could be an index to indicate an environmental problem that is leading to sustainable solution in the future, which is the main analysis of this research.

\section{Objectives}

To propose an indicator to manage with environmental problem from goods and service production leading to sustainable consumption and production in agricultural sector.

\section{Scope of study}

The result is calculated from agricultural sector lines that categorized environmental and natural resources cost as in Thailand's input-output table. The calculation considers input data in input-output table consisting of natural resources materials, energy and transportation, fertilizer and pesticides, and sanitary and similar services. The effect from consumption does not include in environmental cost.

The main calculation from this study is from input-output table of Thailand 2015, which is the latest data. The hypothesis of calculation from input-output table is limited by economic and social description.

\section{Conceptual framework}

The conceptual framework of product sectors selection for shadow environmental cost is based on the objectives and concept of sustainable development. Three supporting concepts are welfare economics of A.C. Pigou, natural resources economics, and ecology economics (Figure 1).

\section{MATERIALS AND METHODS}

Model in this study is related to input-output table (Table 1), whose relationship of the data can be described in mathematics categorized by rows and columns as follows [Leontief, 1986].

A row presents output distribution of product sector i for $\mathrm{n}$ product sector (Xi) and the Gross product of product sector $\mathrm{i}$ can be defined, for 1 $\leq \mathrm{i} \leq \mathrm{n}$, by: 


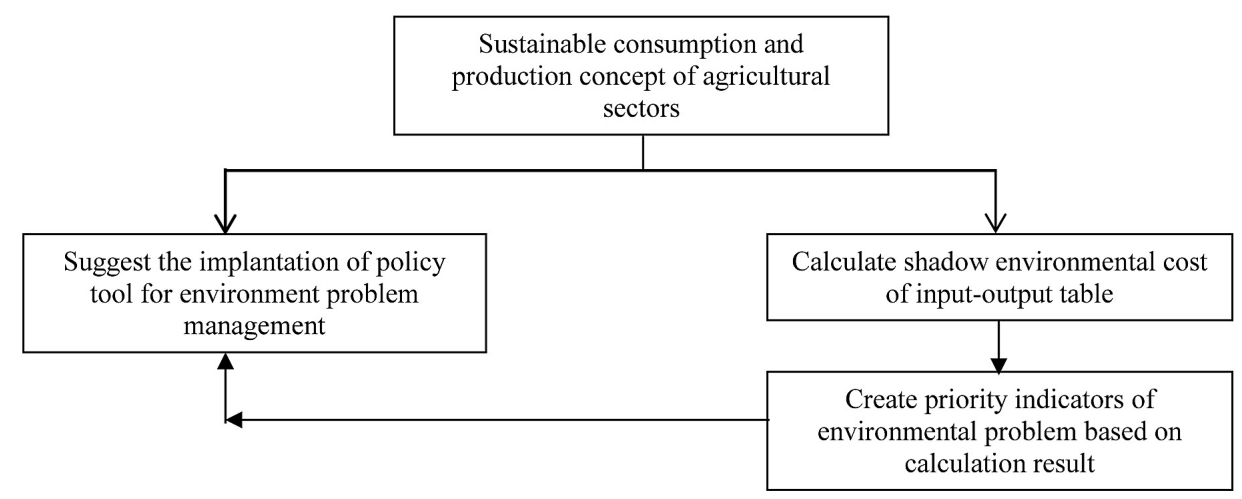

Figure 1. Conceptual framework

Table 1. Input-output table

\begin{tabular}{|c|c|c|c|c|c|c|c|c|}
\hline \multirow{2}{*}{\multicolumn{2}{|c|}{\begin{tabular}{|l|} 
Using sector \\
Producing sector \\
\end{tabular}}} & \multicolumn{2}{|c|}{ Processing sectors } & \multirow{2}{*}{\multicolumn{4}{|c|}{ Final demand }} & \multirow{3}{*}{\begin{tabular}{|c|}
$\begin{array}{c}\text { Total outputs } \\
(\mathrm{X})\end{array}$ \\
$X_{11}$
\end{tabular}} \\
\hline & & \multirow{2}{*}{$\frac{1}{x_{11}}$} & \multirow{2}{*}{$\frac{2}{x_{12}}$} & & & & & \\
\hline \multirow{2}{*}{$\begin{array}{l}\text { Processing } \\
\text { sectors }\end{array}$} & 1 & & & $C_{1}$ & $i_{1}$ & $g_{1}$ & $e_{1}$ & \\
\hline & 2 & $x_{21}$ & $x_{22}$ & $C_{2}$ & $i_{2}$ & $g_{2}$ & $e_{2}$ & $X_{11}$ \\
\hline \multirow{3}{*}{$\begin{array}{l}\text { Payments } \\
\text { sectors }\end{array}$} & \multirow{2}{*}{ Value added } & $I_{1}$ & $I_{2}$ & $I_{\mathrm{C}}$ & $I_{1}$ & $l_{\mathrm{g}}$ & $I_{\mathrm{e}}$ & $\mathrm{L}$ \\
\hline & & $n_{1}$ & $n_{2}$ & $n_{\mathrm{c}}$ & $n_{1}$ & $n_{\mathrm{g}}$ & $n_{\mathrm{e}}$ & $\mathrm{N}$ \\
\hline & Imports & $m_{1}$ & $m_{2}$ & $m_{\mathrm{c}}$ & $m_{1}$ & $m_{\mathrm{g}}$ & $m_{\mathrm{e}}$ & M \\
\hline \multicolumn{2}{|c|}{ Total outlays (X') } & $x_{1}$ & $x_{2}$ & $\mathrm{C}$ & I & G & $E$ & $x$ \\
\hline
\end{tabular}

$$
X_{i}=\sum_{j=1}^{n} X_{i j}+F_{i}
$$

where: $X_{i}$-refers to gross product of product sector $i$,

$X_{i j}$ - refers to product distribution of product sector $i$ of goods and services production for product sector $j$,

$F_{i}$ - refers to the final demand of product sector $i$.

Column shows the structure expenses or cost of goods production for product sector $j\left(X_{i}\right)$ that can be defined, for $1 \leq j \leq n$, by:

$$
X_{i}=\sum_{j=1}^{n} X_{i j}+V_{j}
$$

where: $V_{j}$ - refers to the value added of product sector $j$, only if input value is directly proportional to the output value.

Then $X_{i j}$ can be defined by the relationship of output $(X)$, input coefficient $(A)$ and final demand $(F)$ of production structure for economic system that can be defined by:

$$
\begin{gathered}
X=A X+F \\
X=[1-A]^{-1} F
\end{gathered}
$$

where: $[1-A]^{-1}$ is Leontief inverse matrix or inverse matrix, which is important for economic system analysis by using inputoutput table.

The inverse matrix acts as direct and indirect input coefficient of production supply chain that can be used for supply chain length and intensity calculation. environmental cost of study of each goods production can use the multiplication of environmental cost coefficient and inverse matrix. Finally, the result represents the total effect of supply chain that accumulated environmental cost of each goods production. Besides, the result shows the intensity of backward environmental effect direct and indirect input and output. Furthermore, the result presents names, sectors and intensity of environmental cost that are useful to formulate an efficient policy and environmental problem solving.

Relationship in input-output table affects an output changing of each product sector $(\Delta F)$, which is called multiplier for final goods and services. Equation 5 presents multiplier for final goods and services calculation.

$$
\Delta X=[I-A]^{-1} \Delta F
$$


If shock on final demand $(\Delta F)$ changes, environmental cost will increase $(\Delta E)$. Equation 6 represents the increase of environmental cost.

$$
\Delta E=R[I-A]^{-1} \Delta F
$$

\section{RESULTS AND DISCUSSION}

The results of the environmental costs, real benefit, and multiplier are classified by each category of production. This research can be summarized in Table 2.

The results of the environmental costs, real benefit, and multiplier are classified by each category of the production. This research can be summarized as following:

- The results of the environmental costs of the natural resource materials found that the highest environmental costs of agricultural sector is 026: charcoal and fire-wood. However, when comparing with the average, the sector with higher result than average is 026 : charcoal and fire-wood, which the sector does not have a capacity for production. In contrast, the lowest environmental cost and lower than average is 010 : coconut that has the capacity for production.

- 024: Agricultural services was the highest environmental cost of energy and transportation. It is even higher than the average that does not have the capacity for production. The lowest environmental cost for this section and having capacity for production is 016 : rubber.
- The highest environmental cost of the fertilizer and pesticides is 011: palm oil, while the lowest environmental cost is 024: agricultural services. The highest environmental cost of this module does not have capacity for production, whereas the lowest environmental cost go reversely.

- 017: Other agricultural product defined as the highest environmental cost of the sanitary and similar service, which does not have capacity for production. In contrast, 010 : coconut refineries is the lowest environmental cost of this module and it still has a capacity to produce.

- The highest real benefit in the agricultural sector is 010 coconut, but the lowest real benefit is 024: agricultural services. The lowest real benefit could bring loss in profit.

- The indicator of the environmental issue is an essential tool to decide on policies and strategies of the country. From the analytical result, the benefit from agricultural sector does not mean that the benefit could produce as high as the result. Consequently, it is necessary to calculate the environmental issue in order to prioritize the environmental issue urgently that could achieve the sustainable development. For example, 019: Swine have the highest indicator's value of environmental issues, following by production sector 022 : poultry products of meat respectively. Thus, the production sector 106: rubber must be resolved urgently, and then the lower indicator's value of environmental issues should solve subsequently as the priority.

Table 2. Analysis in top 10 of each production sector

\begin{tabular}{|c|c|c|c|c|c|c|c|c|c|c|c|}
\hline \multicolumn{2}{|r|}{ Multiplier } & \multicolumn{2}{|r|}{ Real benefit } & \multicolumn{2}{|r|}{$\begin{array}{c}\text { Natural resources } \\
\text { materials cost }\end{array}$} & \multicolumn{2}{|c|}{$\begin{array}{c}\text { Energy and transportation } \\
\text { cost }\end{array}$} & \multicolumn{2}{|c|}{$\begin{array}{c}\text { Fertilizer and pesticides } \\
\text { cost }\end{array}$} & \multicolumn{2}{|c|}{$\begin{array}{c}\text { Sanitary and similar services } \\
\text { cost }\end{array}$} \\
\hline value & sectors & value & sectors & value & sectors & value & sectors & value & sectors & value & sectors \\
\hline 2.290 & 019:Swine & 0.941 & 010:Coconut & 0.076 & $\begin{array}{l}\text { 2626:Charcoal and } \\
\text { fire-wood }\end{array}$ & 0.241 & $\begin{array}{l}\text { 024:Agricultural } \\
\text { services }\end{array}$ & 0.165 & 011:Oil palm & 0.001 & $\begin{array}{l}\text { 017:Other agricultural } \\
\text { product }\end{array}$ \\
\hline 2.130 & $\begin{array}{l}\text { 022:Poultry } \\
\text { products }\end{array}$ & 0.883 & $\begin{array}{l}\text { 018:Cattle and } \\
\text { buffalo }\end{array}$ & 0.009 & 023:Silk worm & 0.181 & $\begin{array}{l}\text { 028:Ocean and } \\
\text { coastal fishing }\end{array}$ & 0.094 & 015:Coffee and tea & 0.001 & 015:Coffee and tea \\
\hline 2.025 & 021:Poultry & 0.878 & 025:Logging & 0.008 & $\begin{array}{l}\text { 017:Other agricultural } \\
\text { product }\end{array}$ & 0.124 & $\begin{array}{l}\text { 013:Other crops for } \\
\text { textile and matting }\end{array}$ & 0.054 & 004:Cassava & 0.000 & 019:Swine \\
\hline 1.787 & 029:Inland fishing & 0.873 & 023:Silk worm & 0.008 & 019:Swine & 0.117 & 015:Coffee and tea & 0.053 & $\begin{array}{l}\text { 005:Other root } \\
\text { crops }\end{array}$ & 0.000 & 007:Vegetable \\
\hline 1.732 & $\begin{array}{l}\text { 015:Coffee and } \\
\text { tea }\end{array}$ & 0.872 & 016:Rubber & 0.008 & $\begin{array}{l}\text { 024:Agricultural } \\
\text { services }\end{array}$ & 0.105 & 022:Poultry products & 0.051 & \begin{tabular}{|l|} 
017:Other \\
agricultural product
\end{tabular} & 0.000 & 022:Poultry products \\
\hline 1.633 & 004:Cassava & 0.865 & 003:Other cereals & 0.007 & $\begin{array}{l}\text { 028:Ocean and } \\
\text { coastal fishing }\end{array}$ & 0.104 & 029:Inland fishing & 0.050 & 014:Tobacco & 0.000 & 021:Poultry \\
\hline 1.629 & $\begin{array}{l}\text { 013:Other crops } \\
\text { for textile and } \\
\text { matting }\end{array}$ & 0.855 & $\begin{array}{l}\text { 026:Charcoal and } \\
\text { fire-wood }\end{array}$ & 0.007 & 011:Oil palm & 0.092 & 006:Beans and nuts & 0.040 & 007:Vegetable & 0.000 & 004:Cassava \\
\hline 1.600 & 023:Silk worm & 0.840 & $\begin{array}{l}\text { 027:Other forest } \\
\text { products }\end{array}$ & 0.006 & 015:Coffee and tea & 0.090 & 009:Sugar cane & 0.040 & 012:Kenaf and jute & 0.000 & 025:Logging \\
\hline 1.587 & 011:Oil palm & 0.813 & $\begin{array}{l}\text { 020:Other } \\
\text { livestock }\end{array}$ & 0.006 & 014:Tobacco & 0.090 & 011:Oil palm & 0.038 & 002:Maize & 0.000 & 029:Inland fishing \\
\hline 1.587 & 014:Tobacco & 0.798 & $\begin{array}{l}\text { 012:Kenaf and } \\
\text { jute }\end{array}$ & 0.006 & 022:Poultry products & 0.084 & 019:Swine & 0.031 & $\begin{array}{l}\text { 006:Beans and } \\
\text { nuts }\end{array}$ & 0.000 & $\begin{array}{l}\text { 013:Other crops for } \\
\text { textile and matting }\end{array}$ \\
\hline
\end{tabular}


This research is the pilot study of environmental cost of goods and services production of agricultural sector in the economic system of Thailand by using the database of account system and producing population. Environmental cost contributes to the damage to the environment that has the effect on producers, consumers, and government to manage the expenditures on environmental problems [Bailey et al., 2004; Benoit, 2009; ADB, 2014; TDRI, 2015; Xu, 2010]. The environmental cost could not estimate from the activities occurring in the market. Thus, the estimation of the environmental cost of agricultural sector in Thailand needs shadow environmental cost, which is the economic database showing environmental cost [Pantavisid, 2012]. The information can compare the difference of the environmental cost of agricultural sector that could help to create an environmental problem management indicator [McMullan, 2013; ADB, 2014]. The shadow environmental cost of this study relies on 4 groups of economic data that are cost of natural resources materials, cost of energy and transportation, fertilizer and pesticides, and sanitary and similar services [TDRI, 2005; Pantavisid, 2012].

This research calculates the multiplier of goods and services production in agricultural sector adding in one unit resulting from changing of GDP and the green sector products [Grossmann, 2009; Espinosa, 2011]. The result from the calculation is the information to see economic connectivity of sector in agricultural group resulting from the economic growth and economic net income [Pantavisid, 2012; Ness, 2007; ADB, 2014]. The purpose of environmental problems management is to reduce negative impact from the environmental cost to the economic system. The production size makes a huge difference; even the cost of natural resources and environment was systematically studied and prioritized the significant value of environmental cost to goods and services [TDRI, 2007]. Therefore, other necessary economic data could support the priorities of the environmental problem management [ADB, 2014; TDRI, 2007; Xu, 2010; Zhang, 2012]. The database was created to consider in the multiplier and green value added.

The result of the research in environmental costs of agricultural sector is consistent with the research of Zhang, Y. (2010), Pantavisid, S. (2012) and the result of the real benefit used the research of Sa-nguanwongthong, N. (2013). However, the result of this research could apply with the environmental problems management under the sustainable production concept with the limitation of administrative resources of agricultural sector. It leads to an efficient environmental consumption in the society [TDRI, 2007]. The classification of natural resources and environmental capital of the whole economic system can be implemented for micro sector [ADB, 2014], while the classification from green value added and multiplier is for decision making at macro level [ADB, 2014; Zhang, 2013]. Consequently, analyzing the proper data could lead to efficient an environmental problem management [TDRI, 2007].

Thailand and other ASEAN countries do not create an environmental problem indicator from the analysis of real benefit, environmental cost, and environmental problem that leads to formulate an ineffective policy and plan of the country [ADB, 2014]. The developed countries, in contrast, like Japan and European countries, give an importance to the environmental problem, which the GDP of these countries are showed in green GDP format. This methodology will help the country formulate efficient policy and forecast a situation accurately in the future. Hence, the developed countries can deal with the crisis cause by those problems [TDRI, 2007; Sanguanwongthong, 2013].

\section{CONCLUSION}

From the research it can be concluded that index of environmental cost of natural resource materials, energy and transportation, fertilizer and pesticides, and sanitary and similar service need monitoring intensively are 026 : charcoal and firewood, 024: agricultural services, 011: palm oil, and 017: Other agricultural product, respectively. In addition, the index of environmental problem need observing closely is 019: swine sector. Consequently, the result from this research can be applied to formulate the most efficient policies and strategies in the future.

\section{Acknowledgements}

This work was performed with the approval of the Kasetsart University and Office of the National Economic and Social Development Board. 


\section{REFERENCES}

1. Adams W.M. 2009. Green development: Environment and sustainability in the Third World (2nd ed.). New York, Rutledge.

2. Asian Development Bank (ADB). 1997. Emerging Asia and Challenges. Manila, Asian Development Bank.

3. Asian Development Bank (ADB). 2014. Environment, climate change, and disaster risk management. Manila, Asian Development Bank.

4. Bailey R., Bras B., Allen J.K. 2004. Applying ecological input-output flow analysis to material flows in industrial systems. Part I. Tracing flows. J. Ind. Ecol. 8(1), 45-68.

5. Benoit 2009. Guidelines for social life cycle assessment of products. UNEP-SETAC, G. GuillénGosálbez.

6. Bodini A. 2002. Building a systemic environmental monitoring and indicators for sustainability: What has the ecological network approach to offer? Ecol. Indic. 15, 140-148.

7. Bodini A., Bondavalli C. 2002. Towards a sustainable use of water resources: A whole-ecosystem approach using network analysis. Int. J. Environ. Pollut. 18(5), 463-485.

8. Bojarski J., Laínez A., Espuña, L., Puigjaner. 2009. Incorporating environmental impact and regulations in a holistic supply chains modeling. An LCA approach, Comput. Chem. Eng., 33(10), 1747-1759.

9. Brent C., Labuschagne C. 2006. Social indicators for sustainable project and technology life cycle management in the process industry. Int. J. Life Cycle Assessment, 11(1), 3-15.

10. Brunner P.H. 2007. PH. Reshaping urban metabolism. J. Ind. Ecol. 11(2), 11-13.

11. Chen D.J. 2003. Analysis, integration and complexity study of industrial ecosystems. Doctoral dissertation, Beijing, Tsinghua University.

12. Chen ZM., Chen GQ., Zhou JB., Jiang MM., Chen B. 2010. Ecological input-output modeling for embodied resources and emissions in Chinese economy 2005. Commun Nonlinear SciNumer Simul 15(7), 1942-1965.

13. Duchin F. 2008. Input-output economics and material flows. In: Suh S, editor. Handbook of inputoutput economics in industrial ecology. Cheltenham, Edward Elgar Publishing. Ltd.

14. Duque J., Barbosa-Povoa, APFD Novais A.Q. 2010. Design and planning of sustainable industrial networks: Application to a recovery network of residual products. Industrial and Engineering Chemistry Research, 49(9), 4230-4248.

15. Espinosa A., Walker J. 2011. A Complexity Ap- proach to Sustainability: Theory and Application. London, Imperial College Press.

16. Goedkoop M., Heijungs R., Huijbregts M., Schryver A.D., Struijs J., Van Zelm R. 2009. A life cycle impact assessment method which comprises harmonized category indicators at the midpoint and the endpoint level. The Hague, Ministry of VROM. ReCiPe., First edition

17. Grossmann I.E. 2009. Optimal design and planning of sustainable chemical supply chains under uncertainty. American Institute of Chemical Engineers J., 55(1), 99-121.

18. Hammond A., Adriaanse A., Rodenburg E., Bryant D., Woodward R. 1995. Environmental indicators: A systematic approach to measuring and reporting on environmental policy performance in the context of sustainable development. World resources institute.

19. Harwick J.J., Olewiler N.D. 1998. The Economics of Natural Resource Use. Massachusetts, AddisonWesley.

20. Huang SL., Hsu WL. 2003. Materials flow analysis and energy evaluation of Taipei's urban construction. Landsc Urban Plan, 63(2), 61-74.

21. Hugo A., Pistikopoulos E.N. 2005. Environmentally conscious long-range planning and design of supply chain networks. J. of Cleaner Production, 13(15), 1471-1491.

22. Karna A., Engstrom J. 1994. Life-Cycle Analysis of Newsprint: European Scenarios. Paperi ja Puu, 76(4), 232-237.

23. Kennedy C., Cuddihy J., Engel-Yan J. 2007. The changing metabolism of cities. J. Ind. Ecol. 11(2), 43-59.

24. Lave L.B., Cobas-flores E., Hendrickson C.T., McMichael F.C. 1995. Using Input-Output Analysis to Estimate Economy-wide Discharges. Environmental Science and Technolog, 29(9), 420A-426A.

25. Lee C.L., Huang S.L., Chan S.L. 2009. Synthesis and spatial dynamics of socio-economic metabolism and land use change of Taipei Metropolitan Region. Ecol Model, 220(21), 2940-2959.

26. Lenzen M. 1998. Primary energy and greenhouse gases embodied in Australian final consumption: An input-output analysis. Energy Policy, 26(6), 495-506.

27. Leontief W.W. 1936. Quantitative input and Output Relation in the Economic System of the United State. Review of Economics and Statistics, 18(3), 105-125.

28. Leontief, W.W. 1986. Input-Output Economics (2nd ed.). New York, Oxford University Press.

29. Li S.S., Zhang Y., Yang Z.F., Liu H, Zhang J.Y. 2012. Ecological relationship analysis of the urban metabolic system of Beijing, China. Environ. Pollut. 170, 169-176. 
30. Li Y., Chen B., Yang Z.F. 2009. Ecological network analysis for water use systems: a case study of the Yellow River Basin. Ecol. Model. 220(22), 3163-3173.

31. Liang S., Zhang T. 2011. Urban metabolism in China: achieving dematerialization and decarbonization in Suzhou. J. Ind. Ecol. 15(3), 420-434.

32. Marull J., Pino J., Tello E., Cordobilla M.J. 2010. Social metabolism, landscape change and land-use planning in the Barcelona metropolitan region. Land Use Policy, 27(2), 497-510.

33. McMullan C. 2013. Indicators of urban ecosystem health. Retrieved from http://archive.idrc.ca/ecohealth/indicators_e.html.

34. Ness E., Urbel-Piirsalu S., Anderberg, L., Olsson 2007. Categorising tools for sustainability assessment. Ecological Economics, 60(3), 498-508.

35. Office of the National Economic and Social Development Board. 2015. National Income of Thailand, 2015. Bangkok: NESDB.

36. Office of the Prime Minister, 2007. Budget Document: Expenditure Budget for Fiscal Year Ministry of Public Health. Vol. 3. Bangkok: Bureau of the Budget.

37. Pantavisid S. 2012. Natural Resource and environmental costs of good and service production via sustainable consumption and production approach towards prioritizing the environmental management in Thailand. Doctoral dissertation. Social Development and Environmental Management, School of Social and Environmental Development, National Institute of Development Administration.

38. Pigou, Arthur C. 1960. The economics of welfare/ 4th ed, London: Macmillan.

39. Pinto-Varela A.P., Barbosa-Póvoa A., Novais. 2011. Bi-objective optimization approach to the design and planning of supply chains: Economic versus environmental performances. Computers and Chemical Engineering, 35(8), 1454-1468.

40. Salema M.I.G., Barbosa-Povoa A.P., Novais A.Q. 2010. Simultaneous design and planning of supply chains with reverse flows: A generic modelling framework. European J. of Operational Research, 203(2), 336-349.

41. Sa-nguanwongthong N. 2013. Study of environmental costs for the evaluation of industrial development in Thailand. Doctoral dissertation, Social Development and Environmental Management, School of Social and Environmental Development, National Institute of Development Administration.

42. Simpson D.R., Bradford R.L. 1996. Taxing Variable Cost: Environmental Regulation as Industrial policy. J. of Environmental Economics and Management, 30(30), 282-300.

43. Su M.R., Yang Z.F., Chen B., Ulgiati S. 2009.
Urban ecosystem health assessment based on energy and set pair analysis - a comparative study of typical Chinese cities. Ecol Model, 220(18), 2341-2348.

44. Thailand Development Research Institute (TDRI). 2006. Prioritizing Issues in Natural Resources and Environmental Management. Final report prepared the Thailand Health Fund. Bangkok.

45. Thailand Development Research Institute (TDRI). 2007. Prioritizing Environmental Problems with Environmental Costs. Final report prepared the Thailand Health Fund. Bangkok.

46. Ukaga O., Maser C., Reichenbach M. 2010. Sustainable Development: Principle, Frameworks and Case Studies. London, CRC Press Taylor and Frances Group.

47. Xu, M. 2010. Development of the physical input monetary output model for understanding material flows within ecological-economic systems. J. Res. Ecol. 2(1), 123-134.

48. Yigitcanlar T., Dur D., Dizdaroglu D. 2015. Towards prosperous sustainable cities: a multiscalar urban sustainability assessment approach, Habitat Int., 45(1), 36-46.

49. Yigitcanlar T., Dizdaroglu D. 2015. Ecological approaches in planning for sustainable cities: A review of the literature. Global J. Environ. Sci. Manage., 1(2), 159-188.

50. Yu Y.J. 2008. Syndromic city illnesses diagnosis and urban ecosystem health assessment. Acta Ecol Sin, 28(4), 1736-1747.

51. Zhang Y. 2013. Urban metabolism: A review of research methodologies. Environ Pollut 2013, 178, 463-473.

52. Zhang Y., Li S.S., Fath B.D., Yang Z.F., Yang N.J. 2011. Analysis of an urban energy metabolic system: comparison of simple and complex model results. Ecol. Model. 22(1), 14-19.

53. Zhang Y., Liu H., Li Y., Yang Z.F., Li S.S., Yang N.J. 2012. Ecological network analysis of China's societal metabolism. J Environ Manage, 93(1), 254-263.

54. Zhang Y., Yang Z.F., Fath B.D. 2010. Ecological network analysis of an urban water metabolic system: model development and a case study for Beijing. Sci. Total Environ. 408(20), 4702-4711.

55. Zhang Y., Yang Z.F., Fath B.D., Li S.S. 2010. Ecological network analysis of an urban energy metabolic system: model development, and a case study of four Chinese cities. Ecol. Model. 221(16), 1865-1879.

56. Zhang Y., Zhao Y.W., Yang Z.F., Chen B., Chen G.Q. 2009. Measurement and evaluation of the metabolic capacity of an urban ecosystem. Common Nonlinear Sci. Numer Simul. 14(4), 1758-1765. 